\title{
The Legal Status of Federal Government Corporations
}

\section{CONSTITUTIONALITY}

$A$ DIScUssion of the constitutionality of federal government corporations is unprofitable and speculative if carried beyond a certain well-defined point; and that point is the determination of whether the end desired by Congress is constitutional. When an objective is constitutionally proper Congress may create or incorporate a corporate instrumentality as a means to that end. ${ }^{1}$ The substantiation of this statement traditionally begins with $M c C u l l o c h v$. Maryland ${ }^{2}$ and proceeds through assorted cases until it is involved in a complicated discussion of the legal status of the government's corporations. Thus it is felt that three recent learned writers, Professor Maurice Culp, Professor Oliver P. Field, and Mr. John Thurston, have gone beyond the point of certainty. They have speculated upon (1) just what particular power of Congress will sustain the functions of the various specific federal corporations, ${ }^{3}(2)$ the "reasonable" relations of the activities of such corporations to the powers delegated to Congress, (3) the problein of the delegation of powers to such corporations by Congress, (4) the delegation by Congress of power to the executive to use corporate agencies, (5) the constitutionality of the chartering of federally owned and controlled corporations in a state with (a) specific congressional authority, and (b) merely assumed congressional authority.

These matters are largely speculative because, first, Congress has enacted no general law defining the status of corporations created by it or under its authority and has not followed any uniform rule in cre-

1 See Culp, Creation of Government Corporations by the National Government (1935) 33 Mrcr. L. Rev. 473; Field, Government Corporations: A Proposal (1935) 48 HaRv. L. REv. 775; Thurston, Government Proprietary Corporations (1935) 21 VA. L. Rev. 351, 465, reprinted in Thurston, Governarent Proprietary Corporations in THE ENGrtsh-Spearing CountrIIs (1937). Professor Field says, at page 782: "It seems pretty clear that the national government may use the corporate form as an administrative device for carrying out any power that it can exercise."

2 (1819) 17 U. S. (4 Wheat.) 159, 206: "Let the end be legitimate, let it be within the scope of the constitution, and all means which are appropriate, which are plainly adapted to that end, wbich are not prohibited, hut consist with the letter and spirit of the constitution, are constitutional."

${ }^{3}$ Culp, op. cit. supra note 1, at 511. See Langer v. United States (C. C. A. 8th, 1935) 76 F. (2d) 817. 
ating or authorizing specific corporations, and, second, because court decisions are few and conflicting and the authority of the United States Supreine Court has been heard on but a few points. And such court decisions as there have been are more than likely to have been unusually affected by the philosophic preconceptions of the various judges.

The power of Congress to charter a bank and regulate its operations free from state interference has been upheld in numerous decisions stemming from McCulloch v. Maryland and Osborn v. Bank of the United States. ${ }^{4}$ But the power of Congress to create a corporation to operate a railroad across state lines, and to be free from state interference was upheld by the Supreme Court in $1873,{ }^{5}$ at a time when the development of a national system of railroads was a "manifest destiny." This view was reaffirmed as to bridges and highways in $1888^{7}$ and $1894 .^{8}$ The creation of such agencies in territories is within the plenary power of Congress. ${ }^{9}$

The present study is not concerned with national banks. Of more interest here is the constitutional approval given to the federal land banks, largely on the basis of their being fiscal agencies of the United States. ${ }^{10}$ In regard to the constitutionality of the other corporations discussed herem, it has generally been assumed that they are constitutionally valid. As has been said, the real issue of constitutionality is not concerned with the corporate means Congress may choose to use, but with the substantive ends Congress desires to achieve.

4 (1824) 22 U.S. (9 Wheat.) 738. See also First Nat. Bank v. Union Trust Co. (1917) 244 U. S. 416.

5 Railroad Co. v. Peniston (1873) 85 U. S. (18 Wall.) 5. See the vigorous dissent by Justice Bradley. See also The Clinton Bridge (1867) Fed. Cas. No. 2,900.

6 Luxton v. North River Bridge Co. (1894) 153 U. S. 525, 534.

7 California v. Pacific R. R. (1888) 127 U. S. 1, 39.

8 Luxton v. North River Bridge Co., supra note 6, at 529.

O Ballaine v. Alaska Northern Ry. (C. C. A. 9th, 1919) 259 Fed. 183.

10 "We, therefore, conclude that the creation of these banks, and the grant of authority to them to act for the Government as depositaries of public moneys and purchasers of Government bonds, brings them within the creative power of Congress although they may be intended, in connection with other privileges and duties, to facilitate the making of loans upon farm security at low rates of interest. This does not destroy the validity of these enactinents any more than the general banking powers destroyed the authority of Congress to create the United States Bank, or the authority given to national banks to carry on additional activities, destroyed the authority of Congress to create those institutions." Smith v. Kansas City Title Co. (1921) 255 U. S. 180, 211. Nor may the states tax farm loan bonds issued by the banks. 


\section{IMMUNITY OF THE STATE FROM SUIT}

It is necessary in passing from the question of constitutionality to that of the status of the government corporations to consider briefly the immunity of the state from suit. The rule is that the state cannot be sued without its own consent. This hoary doctrine is imbedded in juristic theory and says simply that the state is sovereign; the sovereign state is the lawgiver; that whether or not he who makes the laws submits to them is a matter of his own choice. A justification for this immunity has been attempted certainly as early as 1922 by $\mathrm{Mr}$. Justice Holmes, ${ }^{11}$ and according to one student, ${ }^{12}$ as early as $1906 .^{13}$ Prior to that time the immunity of the state had been accepted as a matter of course without any attempt at justification, ${ }^{14}$ the cases beginning with Cohens v. Virginia. ${ }^{15}$ When the state or nation does consent to be sued the suitor must comply with the statute granting such permission. ${ }^{16}$ The state may prescribe the terms and conditions of such suits and may withdraw its consent when it sees fit. Where the state cannot be sued, the public funds cannot be reached indirectly by attachment or garnishment. When an officer exceeds the authority conferred by law he is suable; and a similar, though strange, result is reached if he acts under an unconstitutional statute. ${ }^{17}$ Where his acts are lawful, he, as well as the state, is exempt.

11 The Western Maid (1922) 257 U. S. 419, 432.

12 Watkins, the State as a Party Limgant (1927) 57.

13 Kawananakoa v. Polyblank (1906) 205 U. S. 349.

14 WatkINS, op. cit. supra note 12, at 51: "The immunity of a state was assumed as a matter of course. At the Revolution, England was practically the only known country where popular participation in government existed even in a very attenuated form, and even there the subject was deprived of a right of action against the State, under the legal theory that the king, the head of the State, could do no wrong. In other countries the famous statement attributed to Louis XIV closely approximated the truth; the King was the State; an individual possessing, not merely exercising, supreme control, whose coinmand was law, and whose courts were his as much as his lands. It thus scems probable that the doctrine of state immunity was accepted rather as an existing fact by the people of the states, than adopted as a theory. It was a matter of universal practice, and was accepted from the mother country along with the rest of the common law of England apphicable to our changed state and condition. This conjecture seems verified by the fact that in the earher court decisions the doctrine is accepted as existing, but not explained or justified other than on the basis that what is, is right."

15 (1821) 19 U. S. (6 Wheat.) 120. See note to Beers v. Arkansas [(1857) 61 U. S. (20 How.) 527] in (1858) 15 L. ed. 991.

16 United States Ship'g Bd. Emer. Fleet Corp. v. Rosenberg Bros. (1928) 276 U. S. 202, dismissing hbels against Fleet Corporation vessels because not brought in accordance with law. The same applies to the Inland Waterways Corporation. Sevin v. Inland Waterways Corp. (C. C. A. 5th, 1937) 88 F. (2d) 988.

17 See Field, The Effect of an Unconstitutional Statute in the Law of Public Officcrs: 
The whole doctrine has been strongly criticized by learned writers and one thinks that there has been some relaxation of it in recent years. ${ }^{18}$ The idea of the state's responsibility for its acts seems sound.

The whole problem is vitally important in the study of government corporations. Almost every government corporation is given the power to sue and be sued either in the act creating it, in its charter, or in the law under which it is incorporated. ${ }^{10}$ Where the corporation is owned by the government and obtains all its funds from the government, the grant of power to sue and to be sued is a method of giving consent to be sued on contractual relations. The matter is, however, not at all simple because the courts have much difficulty in defining the limits of this consent and in deciding rights and duties in relation, for instance, to tort and bankruptcy.

\section{THE FLEET CORPORATION}

The government corporation which has been involved in the greatest amount of litigation is the United States Shipping Board Emergency Fleet Corporation-later the Merchant Fleet Corporation..$^{20}$ Hence the present status of government corporations as the courts see it is to be found largely in the cases involving this corporation.

The reader should bear in mind the somewhat peculiar status of the Fleet Corporation. ${ }^{21}$ This Corporation was specifically authorized by Congress to develop an American merchant marine which, when developed, was to be turned over to private enterprise. The Corpora-

\section{Liability of Officer for Action or Nonaction (1928) 77 U. OF PA. L. REv. 155.}

${ }^{18}$ WatkIns, op. cit. supra note 12, at 97 . See also Jennings, Tort Liability of Admintistrative Officers (1937) 21 MINN. L. REv. 263, for a well-reasoned essay with constructive proposals.

10 The Fleet Corporation, for example, claimed the power from the District of Columbia law under which it was incorporated.

${ }^{20}$ Some sixty cases on the Fleet Corporation (and then by no means all) have been reviewed in the course of this study. For a fairly complete review of legal status of government corporations, see Schnell, Federally Owned Corporations and their Legal Problems (1936) 14 N. C. L. REv. 238, 337. See also 65 C. J. 1298-1304, for a review of Fleet Corporation cases; Notes (1932) 32 CoL. L. Rev. 881; (1929) 27 Mrch. L. Rev. 786. Both rely largely on Fleet Corporation cases and point out confusions therein. A briefer and earher treatment is found in (1922) 56 Axr. L. REv. 786. Legal status is treated in a general essay by Watkins, Federal Ownership of Corporations (1938) 26 GEo. L. J. 261, 637.

The Fleet Corporation was dissolved by Act of June 29, 1936. 49 Stat. (1936) 1987, 46 U. S. C. Supp. III (1937) \& 1113.

21 Particularly the overlapping of structure, functions, and personnel with those of the United States Shipping Board. 
tion was organized and managed by the United States Shipping Board and, while the personnel of the two agencies was almost identical, the Corporation conducted commercial operations while the Board enforced the regulatory provisions of the Shipping Acts. It was chartered in the District of Columbia and claimed all the corporate powers thereby authorized. ${ }^{22}$ The government owned all the stock and, aside from earnings, furnished its funds. It acted as the direct agent of the President who transferred to it powers delegated to him by Congress.

THE GOVERNMENT CORPORATION AND SOVEREIGNTY

A prinary and essential inquiry in the discussion of government corporations is whether such corporations are equivalent in nature to the government itself--in other words, are their operations an exercise of sovereign power. That such corporations were exercising sovereign power was indicated in Osborn $v$. Bank of the United States. ${ }^{23}$ And that the government was acting in a sovereign character when operatimg the Alaska Northern Railway was the holding of the Circuit Court of Appeals for the Ninth Circuit. ${ }^{24}$ In The Western Maid, ${ }^{25}$ Justice Holnies was of the opinion that the federal corporation there involved was "organized and owned by the United States as an agency for public service-was performing public functions arising out of the war and its sequels." In a later case in which The Western Maid was cited with approval, the Court refused to permit an officer of the United States Navy to charge the United States Grain Corporation for transporting gold in a United States vessel, though he was permitted to exact such a charge from private corporations. ${ }^{26}$ The decision was based upon the near identity between the Umited States and the Grain Corporation.

The Fleet Corporation, as above noted, was chartered in the District of Columbia. This fact impressed one district court and it stressed the congressional choice of the District as the jurisdiction in which the Corporation should be organized as indicative of an intent to treat

22 D. C. CODE (Meyers, 1911) $\$ \$ 605-644$.

23 Supra note 4, at 830. Almost eighty years after Osborn v. Bank of the United States, Justice Shiras in Easton v. Iowa (1903) 188 U. S. 220, 230, quoted the case at 860: "The whole opinion of the court, in the case of $M c C u l l o c h$. Maryland, is founded on, and sustained by, the idea that the bank is an instrument which is "necessary and proper for carrying into effect the powers vested in the government of the United States." '"

24 Ballaine v. Alaska Northern Ry., supra note 9, at 185.

25 Supra note 11, at 432.

26 United States Grain Corp. v. Phillips (1923) 261 U. S. 106, 111, 113-114. 
the Corporation as an "arm" of the sovereign nation. ${ }^{27}$ A somewhat similar position has been taken with regard to frauds against government corporations. So the Act of October $23,1918,{ }^{28}$ making it a crime to defraud, inter alia, a corporation in which the United States holds shares, was held constitutional in United States $v$. Walter. ${ }^{29}$ In upholding the Act the district courts have argued that a successful fraud against the Fleet Corporation would diminish the funds of the United States. $^{30}$

The Corporation has also been held to be a department of the government within the meaning of the Post Roads Act, ${ }^{31}$ indicating a type of relationship that has many variations.

However, the general weight of opinion runs in the opposite direction to the cases which have thus far been discussed; most cases holding that the quality of sovereignty does not attach to the government corporations. Before discussing the contention that such corporations are separate entities, attention should be directed to those opinions which affirm that governinent corporations, though distinct from the government, are yet agencies thereof: This view has substantial support.

\section{THE GOVERNMENT CORPORATION AS AGENT}

Courts may decide that a given government corporation is an agent of the government and dispense entirely with any problems of sovereignty. Thus the district court for Maryland has said:

27 Sloan Shipyards Corp. v. United States Ship'g Bd. Enier. Fleet Corp. (W. D. Wash. 1920) 268 Fed. 624, 627, rev'd, (1922) 258 U. S. 549. The district court was also impressed with the fact that the Fleet Corporation vessels were exempt from ordinary legal liabilities and subjected to admiralty jurisdiction. District Judge Wolverton was impressed in the same manner by the incorporation of the Fleet Corporation in the District of Columbia. Astoria Marine Iron Works v. United States Ship'g Bd. Emer. Fleet Corp. (D. Ore. 1921) 270 Fed. 635, rev'd, (1922) 258 U. S. 549.

2840 STAT. (1918) 1015, 18 U. S. C. (1934) \$\$ 80, 82-85.

29 (1923) 263 U. S. 15. See also Langer v. United States, supra note 3, for the same position on the Reconstruction Finance Corporation. Similarly upheld against a conspiracy at sea directed at one of the Fleet Corporation vessels in United States v. Bowman (1922) 260 U. S. 94.

${ }^{30}$ See note to United States v. Walter, supra note 29, in (1923) $68 \mathrm{~L}$. ed. 137, citing United States v. Carlin (E. D. Pa. 1917) 259 Fed. 904, and United States v. Union Timber Prod. Co. (W. D. Wash. 1919) 259 Fed. 907.

31 United States Ship'g Bd. Emer. Fleet Corp. v. Western Union Tel. Co. (App. D. C. 1926) 13 F. (2d) $308, r e v^{\prime} d$, (1928) 275 U. S. 415 . The Act referred to appears in 14. STAT. (1866) 221, and is headed: "An Act to aid in the Construction of Telegraph Lines, and to secure to the Government the Use of the same for postal, military, and other Purposes." Section 2 gives government telegrams priority at rates annually fixed by the Postmaster-General. 
"It was shown that all the stock of the Fleet Corporation was owned by the government, and that all it did was done for government account, and that all the profits which it made would inure to the government, which would have to stand all the losses. Under such a state of facts, it is unnecessary to inquire whether for all purposes the Fleet Corporation is the government. It suffices that it is a governmental agency, exclusively employed in governmental work, and as such its property is not liable to state taxation."32

The necessity of deciding whether a government corporation is the agent of the federal government may arise in the interpretation of statements made to the effect that the agency relation exists in acts of Congress or in contracts made by the corporation, ${ }^{33}$ or in the determination of whether the United States is the real party of interest in suits brought upon contracts entered into by the corporation. That the United States was a real party in interest and might sue on contracts made by the Fleet Corporation was indicated by acts of Congress permitting the President to dispose of property acquired by the Corporation. The Corporation was admittedly an agency of the United States, and a principal may sue upon the contracts of its agent. The statutes of the United States were held to have become a part of the contract into which the Corporation had entered. ${ }^{34}$

The agency may be one step removed. Thus the Fleet Corporation may act as agent of the United States Shipping Board and be an agent of the federal government, inasmuch as the Shipping Board is beyond doubt an agent of the United States Government. ${ }^{35}$ It is a complete defense against suit for the Corporation to show that it acted solely as a government agency on behalf of the United States. ${ }^{30}$ The rule per-

32 United States v. Coghlan (D. Md. 1919) 261 Fed. 425, 426.

33 The Home Owners Loan Corporation is declared to be "an instrumentality of the United States." 48 STAT. (1933) 129, 12 U. S. C. (1934) \$1463(a).

34 United States v. Skinner \& Eddy Corp. (W. D. Wash. 1925) 5 F. (2d) 708, 710. See also United States v. Czarnikow-Rionda Co. (C. C. A. 2d, 1930) 40 F. (2d) 214, 216, in which Justice Manton took the same position and quoted the Supreme Court to the effect that the Fleet Corporation "has never acted except as agent for the government." 35 United States Ship'g Bd. Emer. Fleet Corp. v. Galveston Dry Dock \& Const. Co. (C. C. A. 5th, 1926) 13 F. (2d) 607 . And the Shipping Board is not liable to suit.

36 Harwood v. United States Ship'g Bd. Emer. Fleet Corp. (D. Conn. 1928) 26 F. (2d) 116, rev'd, United States Ship'g Bd. Merch. Fleet Corp. v. Harwood (1930) 281 U. S. 519, holding the Fleet Corporation bound by its contracts made by itself even though acting as agent of the United States, and that the remedy of suit against the United States directly as provided in the Merchant Marme Act [41 STAT. (1920) 988, 46 U. S. C. (1934) $\S 889$ ] is in addition to the remedy against the Fleet Corporation itself. If the corporation acts ultra vires, it cannot successfully plead its status of agent for the Government as a defense against hability for a tortious act. See Inland Waterways Corporation v. Hardee (App. D. C. 1938) 100 F. (2d) 678, which includes the Flect Corporation in its consideration. 
mitting the real party in interest or the disclosed principal to sue on contracts made by federal corporations has been applied not only to the Fleet Corporation, ${ }^{37}$ but to the United States Housing Corporation, ${ }^{38}$ the United States Spruce Production Corporation, ${ }^{39}$ the United States Grain Corporation, ${ }^{40}$ the Grain Stabilization Corporation, ${ }^{41}$ and the Reconstruction Finance Corporation. ${ }^{42}$

\section{THE GOVERNMENT CORPORATION AS A SEPARATE ENTITY}

A second group of cases insists that government corporations are a separate entity from the government. The best understanding of this view is obtained by an examination of the cases in chronological order.

One of the earliest, and a leading case, is Bank of the United States v. Planters' Bank of Georgia, ${ }^{43}$ in which Chief Justice Marshall affirmed that the Bank of the United States could sue the Planters' Bank in a circuit court, and that the ownership of part of the stock of the latter bank by the State of Georgia could not be offered as a defense on the ground that a corporation is a separate entity and does not partake of sovereignty. ${ }^{44}$ Justice Johnson, dissenting, argued that the Court should go behind the corporate form to the real parties in interest. ${ }^{45}$

There then appears an interesting controversy over notes issued by state banks entirely owned and controlled by their respective states. In 1829 Justice Johnson held that the state of Kentucky did

37 McCarthy v. United States Ship'g Bd. Merch. Fleet Corp. (App. D. C. 1931) 53 F. (2d) 923; Russell Wheel \& Foundry Co. v. United States (E. D. Mich. 1926) 11 F. (2d) 53I, aff'd, (C. C. A. 6th, 1929) 3I F. (2d) 826, 827-828; United States v. Courtright-Dimmick Co. (E. D. Pa. 1928) 28 F. (2d) 142, 143; Crane v. United States (Ct. Cl. 1932) 55 F. (2d) 734. See also The Lake Pachuta (S. D. N. Y. 1930) 56 F. (2d) 627; Enright v. United States (Ct. Cl. 1931) 54 F. (2d) 182; 7 Dec. Coarpr. GeN. No. A-21123 (March 16, 1928) 576.

38 United States v. Stein (N. D. Ohio 1921) 48 F. (2d) 626, also holding the Housing Act of May 16, 1918 [40 Star. (1918) 550, 34 U. S. C. (1934) § 1042] constitutional.

39 Clallain County v. United States (1923) 263 U. S. 341; Addy Co. v. United States (1924) 264 U. S. 239.

40 United States Grain Corp. v. Phillips, supra note 26.

41 See North Dakota-Montana Wheat Growers Ass'n v. United States (C. C. A. 8th, 1933) 66 F. (2d) 573, re Farm Board as arn of the United States.

42 Reconstruction Finance Corp. v. Krauss (D. N. J. 1935) 12 Fed. Supp. 44, 47.

43 (1824) 22 U. S. (9 Wheat.) 398.

44 Ibid. at 399.

45 On the basis of Bank of the United States v. Deveaux (1809) 9 U.S. (5 Cranch) 37 , in which it was held that the Court nay look hehind the corporate form to the nature of the parties conducting the suit. 
not impart its sovereignty to the Bank of the Commonwealth of Kentucky, in which it owned the stock, and that therefore the notes issued by the bank were not bills of credit in the sense prohibited by the Constitution. ${ }^{46}$ This position was upheld some years later with regard to the same bank by Justice McLean, who relied to a considerable extent on the argument that the obligations of the bank were to be met from its own funds and that holders of such obligations could sue the bank. ${ }^{47}$ Justice Story strongly, dissented, pointing out that the bank's notes were, in any reasonable definition, bills of credit within the constitutional prohibition. ${ }^{48}$ Several years later Justice McLean reiterated his position with regard to the Bank of Alabama whose stock was entirely owned by the state and whose board of directors was elected by the state legislature. ${ }^{40}$ Thus it was well settled that a bank owned and controlled by a state was a separate entity not partaking of the sovereignty of the state.

Coming to more recent cases, the circuit court of appeals held that the Panama Railroad Company, though entirely owned and completely controlled by the United States, is a separate entity subject to suit on its own part, and that the relation between it and the United States was not that of principal and agent but of stockholder and corporation, the acts of the corporation not being the acts of its sole stockholder. ${ }^{50}$

This case and the Planters' Bank case are cited in a district court decision that the Philippine National Bank, fifty-one per cent of whose stock must be owned by the Philippine government and eighty-five per cent of which was so owned, and whose affairs were largely con-

46 Bank of Kentucky v. Wister (1829) 27 U. S. (2 Pet.) 204; United States Bank v. Owens (1829) 27 U. S. (2 Pet.) 527. See also dissent by Justices Johnson and McLean in Craig v. Missouri (1830) 29 U. S. (4 Pet.) 249. This case was also on the problem of defining bills of credit.

47 Briscoe v. Bank of Kentucky (1837) 36 U. S. (11 Pet.) 20\%. See also Craig v. Missouri, supra note 46.

48 "The state is the sole owner of the stock of the bank; and all private interest in it is expressly excluded. The state has the sole and exclusive managenent and direction of all its concerns. The corporation is the mere creature of the state, and entirely subject to its control; and I cannot bring myself to the conclusion, that such an important provision in the constitution may be evaded by mere form." Briscoe v. Bank of Kentucky, supra note 47 , at 328 .

49 Darrington v. Bank of Alabama (1851) 54 U. S. (13 How.) 13, 18. See also Curran v. Arkansas (1853) 56 U. S. (15 How.) 323.

50 Panama R. R. v. Curran (C. C. A. 5th, 1919) 256 Fed. 768. The court quotes the Planters' Bank case. But see the report of the Comptroller General to Congress, H. R. Doc. No. 115, 74th Cong. 1st Sess. (1935) 7, where he holds the activities of the Panama Railroad Company and the Panama Canal to be inseparable and often indistinguishable. 
trolled by government officials, was not a department of the government within the meaning of the Post Roads Act.5I

Numerous decisions have affirmed the separateness of the Fleet Corporation. It has been declared not a governinental establishment and therefore suable without the consent of Congress. ${ }^{52}$ Said the Supreme Court: "Notwithstanding all its stock was owned by the United States it must be regarded as a separate entity," and the agents of the Corporation are not agents of its stockholder, the United States. ${ }^{53}$ Nor is it entitled to priority in bankruptcy for its business "was not peculiarly governmental in its nature, but was commercial," and "its powers were not essentially different from those possessed by private corporations." 154

Thus it is deemed to be a separate entity ${ }^{55}$ and therefore not the Umited States in presenting claims in bankruptcy, ${ }^{56}$ and it is subject to the law of the state in which it does business. ${ }^{57}$ Nor can it plead ultra vires as a defense to an action on a contract, in that its business is essentially private. ${ }^{58}$ It is obligated to pay private rates for telegraph services in the eyes of one lower court ${ }^{59}$ but not in those of the Supreme Court. $^{60}$ It may enter into contracts without mvolving the United States Shipping Board or the United States in joint liability. ${ }^{61}$

51 Commercial Pacific Cable Co. v. Philippine Nat. Bank (S. D. N. Y. 1920) 263 Fed. 218. The court cites the narrow construction given to the Post Roads Act by 14 Or. ATI' GEN. (1873) 278, limiting such government rates and priority to departments, officers, and agents of such departments, and also U.S. Treas. Reg. 10 (1918) limiting such privileges to strictly government business.

52 Pope v. United States Ship'g Bd. Emer. Fleet Corp. (S. D. Fla. 1920) 269 Fed. 319. See also Lord \& Burnlram Co. v. United States Ship'g Bd. Einer. Fleet Corp. (N. D. III. 1920) 265 Fed. 955.

53 United States v. Strang (1921) 254 U. S. 491, 493.

54 In re Eastern Shore Shipbuilding Corp. (C. C. A. 2d, 1921) 274 Fed. 893, 899, 902.

55 Traylor Eng. Co. v. United States Ship'g Bd. Emer. Fleet Corp. (E. D. Pa. 1922)

277 Fed. 248. About the same time it was lield that the Panama Railroad Coinpany was subject to suit and its property to seizure the same as any private corporation. Panama R. R. v. Minnix (C. C. A. 5th, 1922) 282 Fed. $4 \%$. See 25 Or. Atr'y GeN. (1905) 465; 27 ibid. (1908) 19.

68 United States v. Wood (C. C. A. 2d, 1923) 290 Fed. 109.

57 Shooters Island Shipyard Co. v. Standard Shipbuilding Corp. (C. C. A. 3d, 1923) 293 Fed. 706.

58 Providence Eng. Corp. v. Downey Shipbuilding Corp. and Chase Nat. Bank of New York v. Umited States Ship'g Bd. Emer. Fleet Corp. (C. C. A. 2d, 1923) 294 Fed. 641, 656. But see note 66 , infra.

59 United States Ship'g Bd. Emer. Fleet Corp. v. Western Union Tel. Co., supra note 31 .

60 Ibid.

61 United States Ship'g Bd. Emer. Fleet Corp. v. Tabas (C. C. A. 3d, 1927) 22 F. (2d) 398, 400: "A corporation, as such, has no authority to sign the name of its stock- 
Attention should now be directed to two Supreme Court opinions, both rendered by Mr. Justice Brandeis. They have been considered definitive as to the status of the Fleet Corporation. In the first, ${ }^{\mathbb{d} 2}$ Justice Brandeis declared, "The Fleet Corporation is thus an instrumentality of the government." Nevertheless, it is not the government itself or 'one of its departments or boards. ${ }^{\text {e3 }}$ It is a separate and distinct entity and not subject to the jurisdiction of the Comptroller General. The accounting of the Fleet Corporation is subject to the supervision of the Shipping Board.

The second case involved the Fleet Corporation and the Western Union Telegraph Company. ${ }^{6.4}$ In his review of the structure and operations of the Fleet Corporation, Mr. Justice Brandeis said that although it is in form a private corporation the "services of the Fleet Corporation were obviously of a public nature. It has never done any business, or conducted any operation, except on behalf of the United States." He pointed out that none but government funds have been used by. the Fleet Corporation and thus any losses borne by it have in reality been borne by the government. This led to his conclusion that "It obviously was not the intention of the Government in employing a corporate agency to deprive itself of the right of priority of transmis. sion and of the lower rate secured through the Post Roads Act." ${ }^{\prime 68}$

Following these decisions other points have been established. If the Fleet Corporation makes an overpayment, the government is entitled to sue as the real party in interest, but the Fleet Corporation may sue or be sued like a private corporation and the government,

holder to a contract and bind him as sole or joint obligor." Freedom from state taxation does not necessarily mean also freedom from suit.

62 United States v. McCarl (1927) 275 U. S. 1, 5.

63 "For tlie Fleet Corporation is an entity distinct from tlie United States and from any of its departments or boards; and the audit and control of its financial transactions is, under the general rules of law and the administrative practice, committed to its own corporate officers except so far as control may be exerted by the Shipping Board." Ibid. at 11.

64 United States Ship'g Bd. Emer. Fleet Corp. v. Western Union Tel. Co., supra note 31 .

65 Ibid. at 422. See Rep. Compt. Gen. (1928) 10. Mr. Comptroller General McCarl thought that since the Fleet Corporation performs government functions and uses entirely government funds, it slould be under the jurisdiction of his office the same as any department of the government.

66 United States Ship'g Bd. Emer. Fleet Corp. v. Western Union Tel. Co. (reversal), supra note 31 , at 423 (concerning the right to sue the Corporation, etc.). According to the facts developed in the case at page 418 , the Smithsonian Institution and the National Home for Disabled Volunteers, both government corporations, lrad been given the right of priority and transinission at the government rate. 
acting through it, must be governed by the rules applying to private parties. ${ }^{67}$ Many of these cases are summarized in a case denying that suit against a corporation owned and controlled by and acting as the agent of the French government is a suit against that government for it is an "entity distinct from its stockholder."

In spite of Mr. Justice Brandeis' strong presentation of Fleet Corporation funds as public funds, it was held that the Fleet Corporation, though the agent of the government, could and did make contracts, with itself as principal, and therefore binding only itself, with the United States excluded as a proper party. ${ }^{69}$

When the matter of state banks came up in its modern form with regard to the North Dakota experiments, the circuit court of appeals cited the Planters' Bank and South Carolina $v$. United States ${ }^{70}$ cases, and concluded that not only was the North Dakota bank a separate entity but that it was engaged in private business and therefore the bank was not exempt from federal taxation. ${ }^{\mathbf{1 1}}$

Howard University has been held not to be a bureau or office under the Department of Interior, ${ }^{72}$ but Columbia Institute for the Deaf has been declared a bureau or office of that department for some

67 United States v. Skinner \& Eddy Corp. (W. D. Wash. 1928) 28 F. (2d) 373.

08 United States v. Deutsches Kalisyndikat Gesellschaft (S. D. N. Y. 1929) 31 F. (2d) 199, 202.

09 Harwood v. United States Ship'g Bd. Emer. Fleet Corp. (C. C. A. 2d, 1929) 32 F. (2d) 680 . The court also went on to point out that the moneys concerned, though originally public, were turned over to and merged with the funds of the Fleet Corporation. This case began as Harwood v. United Sbip'g Bd. Fmer. Fleet Corp., supra note 36, in which it was declared a complete defense to show that the Fleet Corporation had acted solely as a government agency. This view was overthrown by Justice Manton, who was sustained by Justice Stone in United States Ship'g Bd. Merch. Fleet Corp. v. Harwood, ibid., who argued that the Fleet Corporation is bound on a contract made by itself even though acting as agent of the United States, and that the statutory remedy of suit against the United States directly was in addition to the remedy against the Fleet Corporation itself. See also United States v. New Amsterdam Casualty Co. (S. D. N. Y. 1931) $52 \mathrm{~F}$. (2d) 148.

70 (1905) 199 U. S. 437.

71 North Dakota v. Olson (C. C. A. 8th, 1929) 33 F. (2d) 848.

72 "With respect to the Howard University it has been held at various times that it is not a part of any executive department; that the president of the university is not an officer of the United States; that the employees were not employees of the United States within the purview of the acts granting the 5 and 10 per cent increases in the fiscal year 1918; and that the university itself is not a bureau or office of the Department of the Interior. 11 Comp. Dec. 447; 12 id. 412; 23 id. 737; 2 Comp. Gen. 75." 12 Dec. Conprt. Gen. No. A-43419 (1932) 113, at 115. See also Maiatico Const. Co. v. United States (App. D. C. 1935) 79 F. (2d) 418, cert. den., (1935) 296 U. S. 649. 
purposes, but its employees not to be employees of the United States. ${ }^{73}$ Both educational institutions were neatly caught by the language of the Economy Act of June 30, 1932, section 104, ${ }^{74}$ which included any person " $m$ or under" any branch or service of the United States Government or of the District of Columbia. ${ }^{75}$ Thus the corporate independence of these agencies can be directly affected by Congress in the matter of payment of salaries. Again, when it comes to the rule requiring government departments to have their printing done by the Government Printing Office, the Comptroller General decided that Howard University is not a bureau or department within the meaning of that provision. ${ }^{6}$

The Amtorg Trading Company received the same treatment as the French owned company mentioned above. ${ }^{77}$ The Amtorg Company was completely owned and controlled by the Soviet government, but the Court of Customs and Patent Appeals held it to be a citizen of New York State "invested with the right to sue and be sued in the courts of the country,"78 and dissertated at some length on the distimction between private and public functions. ${ }^{79}$ Thus it appears that there is no distinct, clear, and complete definition of the status of government corporations. The courts are fairly well agreed that such organizations are separate entities, but that does not go far in solving the problems that arise.

\section{PUBLIC V. PRIVATE FUNCTIONS}

The problem last mentioned above, the distinction between private and public functions, has received previous notice. A valuable review

78 "It bas been held that employees of the institution were not employees of the United States within the meaning of the various acts granting increase of compensation or bonus to civilian employees of the Government. (23 Comp. Dec. $767 ; 25$ id. 153.) However, it was beld in 6 Comp. Gen. 12 that this institution was a hureau or office of the Departinent of the Interior for the purposes of sections 3709 and 3743, Revised Statutes, and the act of June 17, 1910, 36 Stat. 531, establishing the General Supply Committee." 12 Dec. Compt. Gen. No. A-43419 (1932) 113, at 115.

7447 STaT. (1932) 382, 400.

75 See supra note 73, at 115 .

76 OP. COMPT. GEN. No. A-47704 (March 8, 1933). Nor are the employees of the Panama Railroad Company employees of the United States. See Or. Compt. Gen. No. A-59991 (April 8, 1935) citing Panama R. R. v. Minnix, sulpra note 55.

77 United States v. Deutsches Kalisyndikat Gesellschaft, supra note 68.

78 The Amtorg Trading Corp. v. United States (Ct. Cust. \& Pat. Apps. 1934) 71 F. (2d) 524, 528. See also United States v. Deutsches Kalisyndikat Gesellschaft, supra note 68, (1929) 42 HARv. I. Rev. 1078, (1930) 28 Mrce. L. REv. 457; In re Companhia de Navegacao Lloyd Brasileiro (E. D. La. 1925) 7 F. (2d) 235; Note (1935) 3 Geo. WASII. L. REv. 455.

79 See Helvering v. Powers (1934) 293 U. S. 214. 
of cases on municipal corporations and a statement of the power of the federal government to tax the proprietary operations of a state is to be found in South Carolina v. United States. ${ }^{80}$

It is apparent in the argument that the self-supporting operations such as furnishing gas, light, power, and water are considered to be private operations as distinguished from public functions such as building and maintaining streets, schools, fire and police departments. ${ }^{81}$ The distinction is on a traditional basis since the operation of self-supporting services on a non-profit or tax-reducing plan seems not to have been considered.

In South Carolina v. United States, however, the question was one of the power of the federal government to tax a state operation (license taxes on state agents selling state liquor) normally operated as a private business. To put it another way, the case involved the power of the state to withdraw a subject matter normally taxed by the federal government from that power to tax by the state operating the business itself. This, the Court decided, the state cannot do. ${ }^{82}$

The same problem has arisen with respect to the Fleet Corporation. If the court determines that the corporation is employed by the state to perform what the court considers a public function, then the corporation can no more be sued without the state's consent than the

80 Supra note 70 , at $461-462$. A state acquiring property in another state holds it only as a private corporation-especially if the enterprise is essentially of a private character. Georgia v. Chattanooga (1924) 264 U. S. 472.

Of the confusion in this matter, E. M. Borchard, in Government Liability in Tort (1924) 34 YALE L. J. 129, says: "It is when we come to the municipal corporation as an agency of the public power that we find the greatest confusion to prevail, not only as to the substantive liability or immunity of the corporation in tort, but as to the grounds upon which the liability or immunity, as the case may be, properly rests. In few, if any, branches of the law have the courts labored more abjectly under the supposed inexorable domination of formulas, phrases and terminology, with the result that facts have often been tortured into the framework of a formula, lacking in many cases any sound basis of reason or policy. This is notably the case in the effort to apply the supposedly settled rule that the nuunicipal corporation is not liable for torts committed by its agents in the performance of governmental, political or public functions, whereas it is liable when the tort is committed in the performance of corporate, private or ministerial functions." See also Barnett, Public Agencies and Private Agencies (1924) 18 AMr. Pox. Scr. Rev. 34, 48.

81 Fint v. Stone Tracy Co. (1911) 220 U. S. 107, 172. For a contrary view see Puget Sound Co. v. Seattle (1934) 291 U. S. 619, in which it was held that the city or state may exempt a publicly owned plant fron taxation; that the state may enter into competition with private business in the interest of the public welfare; and that the city so doing is exercising the sovereign power of the state.

82 Accord: Ohio v. Helvermg (1934) 292 U. S. 360 . So also the Bank of the State of North Dakota was considered to be engaged in private business and therefore taxable. North Dakota v. Olson, supra note 71. 
state itself. Since the Fleet Corporation performs a public function, said one court, it cannot be sued in a state court. ${ }^{83}$ But a circuit court of appeals felt otherwise and concluded that the Fleet Corporation is a private business corporation. ${ }^{84}$

But the Fleet Corporation may operate in a public capacity at one time, in a private capacity at another. And for failure to prove itself acting in the former, it was held that the Fleet Corporation was liable to suit under the Pennsylvania compensation act. ${ }^{85}$ The matter may be even somewhat philosophical. In the case of United States Grain Corporation $v$. Phillips, ${ }^{86}$ gold owned by the Corporation was considered to be gold owned by the United States. Why?

"In substance the gold was the property of the United States. It is true that the legal title was in the Corporation, that the property of the Corporation might have been taken to pay a judgment against it, and that in other ways the difference of personality would be recognized. ... But for purposes like the present imponderables have weight. When as here the question is whether the property was clothed with such a public interest that the transportation of it no more could be charged for by a public officer than the carrying of a gun, we must look not at the legal title only but at the facts beneath forms."

There is the further complication that the United States in its business character, that is, the Fleet Corporation, may make contracts which in its sovereign character it may violate and in such violation cannot be held liable. ${ }^{87}$ The court must decide from the evidence before it in what character the United States acted. In the case of the Fleet Corporation it is doubly confusing because, as we have seen, the Fleet Corporation itself may act in either capacity, and the Shipping Board, obviously an arm of the government, can put itself on the same basis as the Fleet Corporation in certain operations. ${ }^{88}$ All this is similar to the problem, or is the problem in different words, of determining when the relation between the United States and the Fleet Corporation is stockholder and corporation, when principal and agent, ${ }^{89}$ and when the government and the Corporation are deemed

83 Southern Bridge Co. v. United States Ship'g Bd. Emer. Fleet Corp., (S. D. Ala. 1920) 266 Fed. 747.

84 Providence Eng. Corp. v. Downey Shipbuilding Corp., sutpra note 58.

85 United States Ship'g Bd. Emer. Fleet Corp. v. Sullivan (1921) $76 \mathrm{~Pa}$. Sup. Ct. 30 , aff'd, (1923) 261 U. S. 146.

86 Supra note 26, at 113.

87 United States v. Warren Transp. Co. (D. Mass. 1925) 7 F. (2d) 161.

88 The No. 34 (D. Mass. 1925) 11 F. (2d) 237.

88 United States Ship'g Bd. Emer. Fleet Corp. v. Tabas, supra note 61. 
identical. ${ }^{90}$ And even after deciding on the stockholder-corporation relationship, the court may be disposed to go behind the surface facts and say that the United States is the real party in interest-the real beneficiary or loser by the operations of the corporation..$^{91}$ There is thus no little confusion among the various judges and courts as to just what is the correct view of the status of government-owned corporations.

\section{STATE TAXATION OF FEDERAL CORPORATIONS}

This confusion is apparent in the important matter of taxation in our federal system. McCulloch v. Maryland, ${ }^{92}$ Johnson v. Maryland ${ }^{93}$ and Osborn v. Bank of the United States ${ }^{94}$ had established firmly the proposition that a state cannot tax that which the courts will permit to be defined as an instrumentality of the federal government. That was, of course, not the end of the controversy over the national banks. The states can exercise no control over national banks save as Congress may see proper to permit." At the same time: "We have more than once held in this court that the national banks organized under the acts of Congress are subject to State legislation, except where such legislation is in conflict with some act of Congress, or where it tends to impair or destroy the utility of such banks, as agents or instrumentalities of the United States, or interferes with the purposes of their creation." ${ }^{\text {" }}$ But Congress has exclusive power over national banks and the tenor of its legislation is to exclude any state regulation. ${ }^{97}$ These banks, it must be remembered, are privately owned and operated for private profit, though instrumentalities of the national government.

A similar controversy arose over the railroads. The Union Pacific Railroad was first incorporated within a state and then incorporated by Congress. The United States owned no stock but the railroad's property was mortgaged to the United States. The corporation derived its powers from state law, exercised its franchise under state law, held its property within state jurisdiction under state protection

90 See Samtr and Betters, The United States ShIPpivg BoARd; Its History, Activities, and ORganization (1931) 25.

01 See text preceding note 45 , supra, and note thereto.

92 Supra note 2.

93 (1920) 254 U.S. 51.

94 Supra note 4. See also Owensboro Nat. Bank v. Owensboro (1899) 173 U. S. 664.

95 The Farmers' \& Mechanics' Nat. Bank v. Dearing (1875) 91 U. S. 29.

86 Waite v. Dowley (1876) 94 U. S. 527.

87 Easton v. Iowa, supra note 23. 
and, in the absence of a specific act of Congress prohibiting taxation, it was subject to tax..$^{98}$ In a little later case the same question arose, the state having incorporated the company after the United States had. The Court, admitting the company to be an agent of the government actually engaged in carrying out the purposes of the government, permitted Nebraska to tax the property of the company. ${ }^{\circ 0}$ There was a strong dissent by Mr. Justice Bradley on the ground that the parallel with the case of Osborn v. Bank of the United States was sufficiently clear to justify the opposite conclusion.

In recent cases, however, where the federal ownership of the corporation is undisputed, the courts have resisted any attempt of the state to tax. Even here, the determination is not final since the court amasses arguments to show that the state tax would be a burden on a governmental function, such as carrying on the war..$^{100}$ And in this case, is should be noted, the corporation concerned was the administratively-created, state-chartered Spruce Production Corporation. In a more recent review of the problem the Court approvingly quoted a prior opinion:

" 'It seems to us extravagant to say that an independent private corporation for gain created by a State, is exempt from state taxation either in its corporate person, or its property, because it is employed by the United States, even if the work for which it is employed is important and takes much of its time." " 101

It then went on to deny that contracts between private corporations and the United States made them instruments of the government and exempt from taxation.

The judges disagree in respect to the taxation of the Fleet Corporation. The circuit court of appeals held that the state cannot tax United States property though the actual title is vested in such an

98 Thomson v. Pacific R. R. (1869) 76 U. S. (9 Wall.) 579.

99 Railroad Co. v. Peniston, supra note 5. See California v. Pacific R. R., supra note 7, in which Justice Bradley voiced the Court's refusal to permit a state to tax a franchise granted by Congress.

100 Clallam County v. United States, supra note 39. See also United States Spruce Prod. Corp. v. Lincoln County (D. Ore. 1922) 285 Fed. 388.

101 Metcalf \& Eddy v. Mitchell (1926) 269 U. S. 514, 525, quoting Baltimore Shipbuilding .Co. v. Baltimore (1904) 195 U. S. 375, 382. The doctrine of immunity from taxation has been receiving reconsideration. See Helvering v. Gerhardt (1938) 304 U. S. 405; Graves v. O'Keefe (1939) 59 Sup. Ct. 595, 83 L. ed. Adv. Ops. 577; Allen v. Regents of Umiversity System of Georgia (1938) 304 U. S. 439. 
agency as the Fleet Corporation. ${ }^{102}$ The real owner and beneficiary is the determining factor. Mr. Justice Woolley, however, dissented on grounds that the real question was whether or not the effect of the tax was to burden a government function. ${ }^{103}$ It has even further been affirmed that real property of the United States held either in proprietary or governmental capacity is exenipt fron taxation. ${ }^{104}$

The United States Housing Corporation sold property as agent of the United States and no taxes could be assessed against the property as long as title remained in the United States; that is, until the property was paid for and the patent certificate issued. ${ }^{105}$ The Supreme Court permitted the state to assess such taxes providing title had in effect passed, but prohibited the forced sale for collection of such taxes unless proper provision was made to protect the interest of the United States. The interest of the United States is paramount to the state's taxing power. ${ }^{106}$

The Tennessee Valley Authority voluntarily pays a sum to Tennessee and Alabama in lieu of taxes. This payment is authorized by Congress. The Warrior River Terminal Company also pays taxes to the state of Alabama though it is a subsidiary of the Inland Waterways Corporation, a government owned and controlled corporation, and Congress has made no such authorization. This voluntary payment

102 United States Ship'g Bd. Emer. Fleet Corp. v. Delaware County, Pa. (C. C. A. 3d, 1927) 17 F. (2d) 40, aff'd (E. D. Pa. 1928) 25 F. (2d) 722. In the first hearing Iustice Woolley based his dissent on McCulloch v. Maryland, supra note 2, and Railroad Co. v. Peniston, supra note 5.

103 See Shooters Island Shipyard Co. v. Standard Shipbuilding Corp., supra note 57, at 716: ". . . though a governmental agency, it [the Fleet Corporation] does not stand in the place of the government so as to share the immunities of the sovereign, but in its transactions as a distinct corporate entity it was bound to observe the law of the state in which it was doing business." See also United States Ship'g Bd. Emer. Fleet Corp. v. Tabas, supra note 61 . In taxation the court may look to the United States as the real owner and beneficiary; in suits the Fleet Corporation may have to stand on its own. For a similar opinion see King County, Wash. v. United States Ship'g Bd. Emer. Fleet Corp. (C. C. A. 9th, 1922) 282 Fed. 950, reh'g den., Oct. 9, 1922.

104 United States v. Hoboken (D. N. J. 1928) 29 F. (2d) 932, citing Cohen and Dayton, Federal Taxation of State Activities and State Taxation of Federal Activities (1925) 34 YALE I. T. $80 \%$.

105 United States v. New Brunswick (C. C. A. 3d, 1926) 11 F. (2d) 476.

$106 \mathrm{New}$ Brunswick v. United States (1928) 276 U. S. 547. The legal division of the Housing Corporation concluded that it could contract with municipalities for public services and could use as a standard of payment therefor, the regular tax rates on similar property. See 1 U. S. Housing CoRp. Rep. (1920) 348-350; ibid. at 58, form of contract for payment in heu of taxes; ibid. at 47-58, discussion of the Corporation's legal problems. See also Alabama v. United States (Ct. Cl. 1930) 38 F. (2d) 897, 900, 902. 
policy has received critical approval ${ }^{107}$ on grounds that it meets the problem of decreasing sources for state taxes, makes possible uniform practice throughout the country, and avoids the litigious potentialities involved in admitting the right of states to tax federal instrumentalities under any circumstances. ${ }^{108}$

Generally speaking, then, the government may tax state proprietary operations, corporate or otherwise, while the state may not tax the corporate mstrumentalities of the federal government-either their operations or their property-without the government's consent.

\section{OTHER STATE RELATIONS}

Other matters of conflict between state and federal jurisdiction in relation to government corporations may be briefly alluded to here. The Supreme Court of Pennsylvania declared that the Fleet Corporation is subject to garnishment in state courts since it is governed by the laws of the District of Columbia and Congress has not withdrawn it from the operation of these laws. ${ }^{109}$ The Fleet Corporation was also declared subject to the compensation law of Pennsylvania. ${ }^{110}$

It seenis in general to be true that corporations owned and controlled by the federal government, whether created by act of Congress

107 Note (1934) 44 YaIE L. J. 326. Sec also Cohen and Dayton, op. cit. supra note 104. The authors advocate that the distinction between public and proprietary agencies is false and should be abolished. At page 822, they conclude: "It seems, therefore, that the rule may be summarized by saying that every exercise of the sovereign power for its proper and normal ends in whatever form and through whatever agency, is wholly free from any burden of taxation levied by the co-sovereignty upon any instrumentality or form of activity."

108 Federal Land Bank of New Orleans v. Crosland (1923) 261 U. S. 374, leid that a state cannot tax the recordation of mortgages owned by the federal land banks. The most complete treatment of the relations between federal government corporations and the states is to be found in Weintraub, Government Corporations and State Law (1939).

100 Haines v. Lone Star Shipbuilding Co. (1920) $268 \mathrm{~Pa} .92$, 110 Atl. 788. Legis. (1936) 36 Cor. L. REv. 809,816 , n. 35 (citing conflicting cases on garnishment of government corporations).

The Home Owners Loan Corporation Field Manual, XIV, (16), 12, states that the Home Owners Loan Corporation is not subject to garnishment. Tbis was overruled in Gill v. Reese (1936) 53 Ohio App. 134, 4 N. E. (2d) 273. Sec Note (1937) 17 B. U. L. REv. 191-198, for argument sustaining the rightness of this decision. Central Market v. King (Neb. 1937) 272 N. W. 244, held the Corporation to answer as garnishee because it is a separate entity not performing the ordinary governmental functions. Houne Owners Loan Corp. v. Hardie \& Caudle (Tenn. 1936) 100 S. W. (2d) 238, beld the Corporation not subject to garnishment because there is no evidence that Congress intended it to be. Sec discussion in (1938) 22 MINN L. REV. 293.

110 United States Ship'g Bd. Emer. Fleet Corp. v. Sullivan, supra note 85. 
as the Home Owners Loan Corporation, ${ }^{111}$ by administrative action under Congressional authorization as the United States Housing Corporation, or chartered in states as the Federal Subsistence Homesteads Corporation subsidiaries, need not qualify as foreign corporations or pay any franchise tax or license fee though certain service fees may be charged in the state where such corporation is chartered.112

Many other problems of inter-governmental relationships arise, but most of them are not peculiar to the corporate form.

\section{SUABIIITY OF GOVERNMENT CORPORATIONS}

As has been apparent through most of the cases discussed, government corporations have been considered separate entities so that they may be sued. Suit may be authorized expressly in the act of Congress creating the corporation, or may be implied by reason of the fact that Congress chose to permit such an agency to be used. ${ }^{113}$ In either case it is looked upon as Congress giving its consent that the government may be sued. There are, however, certain nuances on suability which are of interest.

In the first place, many judges think that such corporations ought to be suable; or, that the government ought to be suable when it engages in commercial operations. Justice Learned Hand displays his sentiments most frankly in an early case on the Fleet Corporation:

"Moreover, it is in general highly desirable that, in entering upon industrial and commercial ventures, the governmental agencies used should, whenever it can fairly be drawn from the statutes, be subject to the same liabilities and to the same tribunals as other persons or corporations similarly employed." 114

111 Field Manuas, Hodie Owners Loan Corporation, VI, (2), 5: "The Home Owners' Loan Corporation is a Federal corporation and is not subject to the various statutes requiring the registration of foreign or domestic corporations in the states and the payment of fees in connection therewith. It is entitled to sue and be sued in all courts of competent jurisdiction, Federal or State."

112 Glick, The Federal Subsistence Homestead Program (1935) 44 YaLE L. J. 1324, 1349 , n. 75 (reviewing cases and opinions).

113 Corporations where such a provision is specifically part of the creating or incorporating act of Congress include the Home Owners Loan Corporation, Reconstruction Finance Corporation, Tennessee Valley Authority, and Federal Deposit Insurance Corporation. General practice has been held to imply that Congress intended a corporation to be suable even if there were no statutory provision to that effect. Keifer \& Keifer v. Reconstruction Finance Corp. (1939) 59 Sup. Ct. 516, 83 L. ed. Adv. Ops. 512, holding the Regional Agricultural Credit Corporations to be suable.

114 Gould Coupler Co. v. United States Ship'g Bd. Emer. Fleet Corp. (S. D. N. Y. 1919) 261 Fed. 716, 718. The justice also dwells on the intentions of Congress and says 
And this feeling has been expressed also by Mr. Justice McReynolds in a case dealing with the Director General of the Railroads. ${ }^{115}$

Like Justice Hand, Justice McReynolds also commented on the intention of Congress with regard to suability. The inferential chain of reasoning in determining congressional intent in respect to the Fleet Corporation is well illustrated in the following:

"We are certainly justified in assuming that Congress, by its legislation on the subject, intended that the obligations which necessarily must be incurred will be met either by the United States or this corporation, and that it was further intended that the existence and extent of such obligations should be determined either as against the United States or as against the corporation, and as Congress has not seen fit to have the United States directly assume the obligation, and has not provided any way in which any questions which may arise may be determined in favor of or against the corporation. If the above inferences are justified, then one of two things follows: Either that the corporation is not immune from the service of process by virtue of its public character, or if it is the United States, in doing whatever it does, then the United States has consented to the bringing of appropriate actions against it." 116

The question of intent applies to corporations created by states also on the basis of intention to perform a "public" or "private" function. ${ }^{117}$ And as appears in many cases, the courts think Congress adopted the corporate form to facilitate the commercial operations of the government--especially the making of contracts. ${ }^{118}$ The possible private ownership of the Fleet Corporation was taken as an indication of congressional imtent. ${ }^{119}$ And its incorporation in the District of Columbia was several times noted as indicative of the intention of Congress to have it suable. ${ }^{120}$ One court attempted to distinguish the United States' sole ownership of the Alaska Northern Railway from its equally sole ownership of the Panama Railroad Company on grounds that one was public purpose and the other private enterprise. ${ }^{121}$ And on another occasion when the question of the moral debt

that without doubt a conspiracy to defraud the Fleet Corporation, at least when acting as the President's delegate, is a fraud against the United States.

115 Mellon v. Michigan Trust Co. (1926) 271 U. S. 236, 239, quoting from Davis v. Pullen (C. C. A. 1st, 1922) 277 Fed. 650, 655.

116 Commonwealth Finance Corp. v. Landis (E. D. Pa. 1919) 261 Fed. 440, 444. 117 Southern Bridge Co. v. United States Ship'g Bd. Emer. Fleet Corp., supra note 83. 118 United States Ship'g Bd. Merch. Fleet Corp. v. Harwood, supra note 36.

119 Lord \& Burnham Co. v. United States Ship'g Bd. Emer. Fleet Corp., supra note 52 .

120 But see Justice 'Taft's dissent in Sloan Shipyards Corp. v. Umited States Ship'g

Bd. Emer. Fleet Corp., supra note 32.

121 Ballaine v. Alaska Northern Ry., supra note 9, (1920) 20 Cor. L. REv. 217. 
or responsibility of the United States arose, the court affirmed that the matter was to be decided by Congress exclusively. ${ }^{122}$

Aside from specific provisions in the creating act, ${ }^{123}$ Congress may, of course, subject any agency of the government to suit as it sees fit. ${ }^{124}$ In the case of the Fleet Corporation Congress provided in the Shipping Act of $1916^{125}$ that all United States vessels employed solely as merchant vessels had the status of private vessels. ${ }^{126}$

All the cases discussed above as holding that government corporations are separate entities, have, of course, held them suable. A large number of cases have so held the Fleet Corporation. ${ }^{127}$ Likewise a number of cases have held the Panama Railroad Company to be a separate entity, subject to suit, and that a conspiracy against it was not an attempt to defraud the United States. ${ }^{128}$ And the United States Sugar Equalization Board was denied the defense of claiming itself an agency of the United States. ${ }^{129}$

Furthermore, some cases hold such corporations to be subject to the jurisdiction of state courts and to laws of the states. In addition to the cases already cited relating to the Fleet Corporation, the United States Sugar Equalization Board, chartered in a state, has been held subject to the state laws governing suability. Said the court:

122 United States Sugar Equalization Bd. v. P. De Ronde \& Co. (C. C. A. 3d, 1925) 7 F. (2d) 981.

123 See note 113 , supra.

$12 \pm$ Mellon v. Michigan Trust Co., supra note 115.

12539 STAT. (1916) 730, 46 U. S. C. (1934) \$808.

126 The Lake Monroe (1919) 250 U. S. 246.

127 See previous discussion in the text on government corporations as separate entities. The Fleet Corporation was held subject to suit without the consent of Congress in Pope v. United States Ship'g Bd. Emer. Fleet Corp., supra note 52, and subject to garnishment in Cominonwealth Finance Corp. v. Landis (E. D. Pa. 1919) 261 Fed. 440, and suable for a tortious act, Astoria Marine Iron Works v. United States Ship'g Bd. Emer. Fleet Corp., supra note 27. Other cases affirming the suability of the Fleet Corporation or permitting it to be sued but not mentioned heretofore are: United States Ship'g Bd. Emer. Fleet Corp. v. South Atlantic Dry Dock Co. (C. C. A. 5th, 1924) 300 Fed. 56; Lembeck v. United States Ship'g Bd. Emer. Fleet Corp. (C. C. A. 2d, 1925) 9 F. (2d) 558; United States Ship'g Bd. Emer. Fleet Corp. v. Greenwald (C. C. A. 2d, 1927) 16 F. (2d) 948; Howarth v. United States Ship'g Bd. Emer. Fleet Corp. (C. C. A. 2d, 1928) 24 F. (2d) 374; Fidehty Trust Co. of New York v. United States Ship'g Bd. Emer. Fleet Corp. (S. D. N. Y. 1926) 15 F. (2d) 600. There are inany others. See, for example, Schnell, op cit. supra note 20, at 250-251, n. 33.

128 Salas v. United States (C. C. A. 2d, 1916) 234 Fed. 842 ; Panama R. R. v. Curran, supra note 50; Panama R. R. v. Minnix, supra note 55.

129 Federal Sugar Refin. Co. v. United States Sugar Equalization Board (S. D. N. Y. 1920) 268 Fed. 575. 
"If the sovereign thus chooses as its agent a state corporation which can be sued it cannot by ipse dixit deprive one injured by such an agent of the right to sue. The state of Delaware allowed defendant to be created, but as a condition of its creation and existence it afforded the right to any one to sue the corporate being which it thus created. ..." 130

What are the exceptions or limitations on suability? The United States, of course, cannot be sued for torts of its agent without its consent. ${ }^{131}$ The courts, however, are not always sure as to whether or not the consent has been given with respect to a specific corporation. Suit to set aside a contract agamst the Fleet Corporation made under duress was denied by a district court but permitted by the Supreme Court, ${ }^{132}$ and the latter Court permitted suit for the tortious act of its servant agamst the Panama Railroad Company. ${ }^{133}$

\section{SUMMARY}

This survey of the legal status of federal government corporations would seen to warrant the following generalizations:

$130 \mathrm{Ibid}$. at 584. Apparently jurisdiction over federally owned corporations is concurrent in state and federal courts. "However, in order to confer jurisdiction on the federal courts, either originally or on removal, the necessary jurisdictional facts as set out in the Judicial Code ... [36 STAT. (1911) 1091, 28 U. S. C. A. (1927)'§ 41] must be present. Thus, for the purpose of determining jurisdiction, as well as suability, the government owned corporations are treated as distinct entities and general rules are applied." Schnell, op. cit. supra note 20, at 271.

131 The Western Maid, supra note 11 . See the extended critical study by Borcbard, op. cit. supra note 80. See also Federal Sugar Refin. Co. v. Umited States Sugar Equalization Board, supra note 129 (holding the Sugar Equalization Board suable for tort); Keeley v. Keer (D. Ore. 1921) 270 Fed. 874 (holding the Reconstruction Finance Corporation not liable for tort); and for cases in which the Panama Railroad Company was held liable for torts but in which the question of immumity was not raised, see Schnell, op. cit. supra note 20, at 254, n. 46.

132 Sloan Shipyards Corp. v. United States Ship'g Bd. Emer. Fleet Corp., supra note 27. See also Astoria Marine Iron Works v. United States Ship'g Bd. Emer. Fleet Corp., supra note 27.

133 Panania R. R. v. Bosse (1919) 249 U. S. 41. And see the following cases on the Fleet Corporation: Cohn v. United States Ship'g Bd. (C. C. A. 6th, 1927) 20 F. (2d) 56; Galveston Dry Dock \& Const. Co. v. United States Ship'g Bd. Merch. Fleet Corp. (C. C. A. 5th, 1929) 31 F. (2d) 247; United States Ship'g Bd. Emer. Fleet Corp. v. Galveston Dry Dock \& Const. Co., supra note 35 . See also Whiteside v. United States (1876) 93 U. S. 247; McCarthy v. United States Ship'g Bd. Merch. Fleet Corp. (App. D. C. 1931) 53 F. (2d) 923. In Schevitsky v. Home Owners Loan Corporation (E. D. Mo. 1939) 2 Fed. Supp. 311, the court decided that the Home Owners Loan Corporation could not be sued for tort on nere inference from the statute, while in Inland Waterways Corporation v. Hardee, suspra note 36 , at 689 , the government corporation was held "liable for its wrongful acts just as in the case of any private corporations." The latter case, however, was one involving ultra vires acts on the part of the corporation. 
Corporations owned and controlled by the federal government (created or authorized by act of Congress) are constitutional if their purposes are within the powers of Congress. They are instrumentalities of the government, and therefore they may act as the government itself or as the direct agent of the government, in which case they can be sued only if an act of Congress or an implied intention of Congress gives consent. Whenever they so act as agent, the government as real party in interest may be a party to the suit, or may sue on contracts made by the corporation. In general the courts consider government corporations to be separate entities, so that unless Congress has specifically decreed limitations they are considered suable (by implied consent) under rules and regulations applicable to private corporations. But the courts may find the United States to be a real party in interest and the corporation to be performing a public function with public funds, in which case the courts may imply limitations on suability. Specific corporations may be considered to be departments of the government within the meaning of certain acts, and not within the meaning of others, and therefore their employees may be subject to the effects of some statutes but not to those of others. All government owned and controlled corporations are not subject to state taxes on either property or operations without the direct consent of Congress, but in general all such corporations conduct their operations subject to the laws of the states in which they operate unless the courts find that Congress has decreed or implied otherwise. Inasmuch as Congress has not seen fit to enact a law setting forth the powers, functions, obligations, and status of such corporations, nor to employ a uniform method of creation, much is left to the interpretation of the Attorney General, the Comptroller General, other department heads, and the legal staffs of the corporations. Finally, the status of such corporations before the courts is not certain beyond the inconclusive generalizations given here. ${ }^{134}$

The intention of this paper, therefore, has been to give some insight into the problem of determining the status of government corporations, to mdicate some of the various and conflicting issues involved, and to show that until Congress acts and the Supreme Court affirms, generalizations as to the status of government corporations must of necessity be tentative.

Though some of the cases quoted in the article have included corporations chartered in states by administrative action under congres-

134 For a similar study of status see Glick, op. cit. supra note 112, at 1356-1358. 
sional authority, these corporations are submerged in a fog of doubt. The Comptroller General has been definitely antagonistic toward them. ${ }^{135}$ The Attorney General has recommended that incorporation of such corporations in the District of Columbia is to be preferred. ${ }^{130}$ There is even doubt as to their constitutionality, ${ }^{137}$ although such doubt rests obviously on a theory of American government rather than any specific provision of the Constitution. The corporations which have aroused most antagonism in this respect have been certain New Deal corporations which were created by administrative action with only a vague implication of congressional authority, and which, through their verbose and all-inclusive charters, gave the corporations nearly unlimited powers and certain members of Congress nearly unlimited jitters. ${ }^{138}$ Judicially, their status is as yet indeterminate.

Harvey Pinney.

DEPARTMENT OF GOVERNMENT,

NEW YORK UNIVERSITY.

135 Treated at some length in another section of the general study. See also McDiarmto, Government Corporations and Federal Funds (1938).

136 Letter to the Secretary of the Interior, Feb. 7, 1934.

137 See references cited in note 1, supra, and also McIntire, Government Corporations as Adntinistrative Agencies: An Approach (1936) 4 Geo. WASH. L. REv. 161.

$138 \mathrm{~A}$ partial list of such corporations and an example of the jitters may be found in (1935) 79 CoNG. REC. 1546-1561. 